lattal foglalkozó jogszabály megalkotását tartja indokoltnak. Részletesen kimunkált normatervezetet olvashatunk a szóban forgó vizsgálat szabályozási variánsaként. Javaslatai hasznosíthatók lehetnek hazai viszonylatban is, tekintettel arra, hogy a környezeti hatásvizsgálat részletes jogi szabályozásával mindezideig adós a magyar jogalkotás.

A VI. fejezet a környezetvédelmi ellenőrzés elméleti kérdéseit, az ezt megvalósitó szervek rendszerét és hatáskörét elemzi az ipari termeléssel összefüggésben. E tevékenység két, egymástól elkülönült formában nyilvánul meg: az egyes ágazati ipari minisztériumok irányító munkájának egyik tevékenységi eleme, illetve a gazdaságirányítástól független ellenór zés. Az utóbbi hivatott szolgálni az össztársadalmi környezetvédelmi érdekek érvényes ülését. Ezen ellenőrzési forma ad lehetőséget továbbá a környezetvédelmi problémák egységes szemléletú megoldásához, elősegítheti az e téren alapvető fontosságú koordináció ha tékony megvalósulását. $\mathrm{Az}$ e funkciót ellátni hivatott szervezeti háttér széttagoltságának ellentételezéseként - pozitiv példaként - mutatja be és értéke lì a Szovjetunió néhány köztársaságában létrehozott környezetvédelmi állami bizottságok te vékenységét.
A monográfia utolsó fejezete az ösztönzés kérdését vizsgálja a környezet jogi védelmének rendszerében. A szerzố vázolja az ösztönzés szovjetunióbeli helyzetét, mely a mi viszonyainkhoz hasonlóan számos, a környezetvédelmi érdekek érvényesülését gátló elemet tartalmaz. Ennek feloldására megoldási javaslata nincs, ami érthető is, hiszen önmagában a jog eszközeivel az érdekkonfliktusok nem rendezhetők. A fejezet foglalkozik még a környezetvédelmi jogi felelősség alapvetó formáival, érvényesülésével az iparban. Érdekes gondolatok olvashatók a környezetvédelmi tevékenységre ösztönzés pszichológiai aspektusairól a kötet utolsó oldalain.

Mint e rövid tartalmi ismertetésből is kider ül, igen érdekes, magas színvonalú, az elméletet és a gyakorlatot jól ôtröző munkát tükröz e monográfia. A választott bonyolult problémakör valamennyi kérdéséhez kritikus szemlélettel közelít, problémacentrikus, ugyanakkor következtetéseiben megalapozott, átgondolt. Hasznos olvasmány lehet mindazoknak, akik ma hazánkban a környezeti állapot romlásának megállításán fáradoznak mind az irånyítás, mind a tudományos kutatás ter ületén.

BENKÓNÊ LODNER DOROTTYA

\title{
ERDÖSI FERENC: A TÁRSADALOM HATÁSA A FELSZINRE, A VIZEKRE ÉS AZ ÉGHAJLATRA A MECSEK TÁGABB KÖRNYEZETÉBEN
}

\author{
Akadémiai Kiadó, Bp. 1987. p. 228
}

\begin{abstract}
A hosszas nyomdai átfutás miatt a szakma is nagy érdeklődéssel várta ezt a könyvet. Ez azzal is magyarázható, hogy ritkán jelent meg eddig hasonló mú, azok is csak ,kis területre, területegy ségre korlátozták vizsgálataikat, tárták fel az antropogén hatásokat az egyes szférákra és dolgozták ki ezen hatások komplex területi rendszerét", illetve csak egyegy geoszférára gyakorolt társadalmi hatásokkal foglalkoztak.
\end{abstract}

A könyv szerzője ERDŐSI FERENC, az MTA RKK Dunántúli Tudományos Intéze tének osztályvezetôje, aki a Tér és társadalomban megjelent közlekedésföldrajzi irásával nem ismeretlen az olvasók elốtt.
$A z$ íó jelentôs adatgyưjtésre, dokumentációra és nagy szakirodalmi ismeretekxe támaszkodva alapos és színvonalas elemzést végzett. Ez a munka korszerü szemlélettel mutatja be a társadalom és a természet kapcsolatát, igy alapvető mü lehet az ,egységes", földrajzi szemlélet kialakításában.

A könyv négy fỏ fejezetre oszlik.

Az első fejezetben a szerző célul tűzi ki, hogy elemezze a társadalmi termelés néhány ágának az egyes geoszférákra gyakorolt hatását, értéke łje a lényeges és tartósnak igérkező változások gazdasági következményeit, meghatározza a természeti viszonyokban bekövetkezett vảltozás intenzitását és dinamikảát, a geoszfé- 
rák és kiváltó tényezők szerint, továbbá kísérletet tegyen a változások területi rendszerének felvázolására. Ezen kivül az a cél is vezérli, hogy „munkánk dimenzióiban is megfeleljen a területi tervezést megalapozó regionális kutatások elvárásainak, a területi tervezésben való hasznosíthatóság követelményeinek" - írja a 8. oldalon.

A vizsgálat a Dráva-Kapos-Hidas-patak, a Sió-torkolat, illetve a Dunától a Gyöngyöspatak nyugati ágáig tartó területre - tehót nem egy tájegységre - terjed ki. Az elemzéseket - ahol lehetôség volt rá - a római kortól napjainkig elvégezte. Természetes, hogy legrészletesebben az utóbbi 100-150 év felszínt, vizeket és éghajlatot befolyásoló antropogén hatásait vizsgálta.

A bevezetésben leírja a mezo- és makroszintủ területi egységekre alkalmazott módszereket: a forrásmunkák, a régi, még használható térképek elemzését, a terepmunkát, a kísérleteket, az alaptérképek készítését és felhasználását, illetve a késő́bbi fejezetekben statisztikai, kartografikus és összehasonlító módszerekról tesz említést.

A második fejezetben a szerző az antropogén beavatkozások hatásának hazai és külföldi vizsgálatairól, kutatástörténeti elózményeiröl ir. A Ritter-tanítványoktól egészen napjainkig követhetjük nyomon a geográfusok egy csoportját, akik antropogén geomorfológiai kutatásokat is végeztek. Az 1970-es évektól a Római Klub jelentése nyomán Magyarországon is fokozódott - a földrajztudomány érdeklődése a környezeti problémák iránt. A könyv írója szerint „miként a tájra, úgy az egész környe. zetre vonatkozóan egyre inkább az az álláspont alakul ki, hogy nemcsak lehetséges, hanem egyenesen kívánatos, hogy komplex szemlélettel vizsgáljuk az adott területegységeket, mert a természet, s a gazdaságföldrajz a maga területén csak a kérdés egyik oldalát látja, de a táj vagy a földrajzi környezet egymásba fonódó, egymást feltételező természeti és gazdasági potenciálját csak közös munkával lehet feltárni". Ez a rövid summázata a második fejezetnek, s egyben a könyv egyik alapvetơ tartalmi mondanivalója is.

A következő fő fejezet ritkaságszámba menő részletességgel elemzi a vizsgált régió földrajzi környezetének állapotát. Közel 130 oldalon, 63 ábra, 15 táblázat és a 62 kép segitségével mutatja be a termelés fốbb ágazatainak hatását a környezetre és néhol a be- következett változások visszahatását is a társadalmi-gazdasági viszonyokra. Az első részben a bányászat szerepével - ezen belül is először a szénbányászattal és ennek hatásaival foglalkozik. Bemutatja a hányókon megfigyelhető morfológiai formákat és hatótényezőket is. Fontos megállapítása, hogy a természetes körülmények között végbemenő folyamatok megfigyelésekor a valóságot pontosabban tükröző ismereteket nyerhetünk, mint kísérletkor. Saját mérései alapján - melyek időtartama 4-8 év - mutatja be az alábányászás következtében berogyott formák fejlődését is.

A morfológiai értéke lés után a bioszféra más ter ületein veszi sorra a változásokat. Êrdekes, hogy míg az ország sîkvidékein (különösen a Tiszántúlon) a talajvíz szintjének emelkedését tapasztaljuk a csökkenô talajvízkivétel és a növekvő rétegvízfelhasználás illetve a csatornázottság hiánya miatt, addig a bányaterületeken és környékén talaj- és réteg. vizsüllyedés következett be. Ennek egyéb vonatkozásait más magyarországi példából is ismerhetjük (Hévíz, Tapolca, Budapest). A szerző 1964-1967 években szisztematikusan kiválasztott időjárási helyzetekben végzett mérései alapján nyerhetünk képet a bányászatnak a helyi klímára gyakorolt hatásáról.

A következőkben foglalkozik az uránércbányászattal. „Sajnos” - ahogy a szerző is írja - ...,állambiztonsági érdekek miatt az uránbányászat más környezeti hatásairól nem áll rendelkezésünkre sem adat, sem fénykép, sem térkép". Pedig jó lenne foglalkozni ezzel a kérdéssel is, hiszen köztudott, hogy napjainkban a közvélemény figyelme egyre inkább a jelen és a jövő nagy energiaforrása felé fordul, amely hatalmas lehetôségeket, de borzasztó veszélyeket is magában rejt.

Végül a térben kevéssé koncentrált építōanyag-kitermelésról ir.

Nyilvánvaló, hogy az ember által előidézett környezetmódosulás visszahat a társadalomra. Fontos szempont, hogy a már lemüvelt bányák területén megszervezzék az újrahasznosítást, ,amely nem merülhet ki a mezőés erdôgazdálkodási igénybevétellel, lehetőség nyílhat idegenforgalmi hasznosításra is".

A fejezet következô részei a közlekedés, a zárt települések, a mezö- és erdőgazdálkodás és a vízrendezés hatásaival és következményeivel foglalkoznak. Az elózőektől eltérve ebben a részben már a vizsgált terület egészérôl kaphatunk tájékoztatást, amelyben mezo- és 
makroléptékü vizsgálati módszereket alkalmaz a szerzö. Megállapítása szerint az emberi települések - különösen a nagyvárosok okozta környezetváltozás hatása mindhárom szférában jelentôs. Rámutat arra, hogy a közlekedési pályák épitése viszonylag kis területsávon, de annál számottevőbb anyagkicserélődéssel járt. Kiemeli, hogy a mezôgazdaság különbözó ágai (a szólómúvelés, birkalegeltetés és a földmúvelés, stb.) különböző kitettségú helyeken, más-más módon, de mégis komplexen hatnak a lejtók lepusztulására és a korrelativ üledékek felhalmozódására. Feltétlenül figyelemre méltó a terület határvonalait képező Duna és Dráva hosszának felére csökkenése és az, hogy az utóbbi évtizedekben már ezen a területen találjuk a hazai halastavak és víztározók közel egyharmadát.

A negyedik fejezet - a szintézis - az antropogén hatások föbb jellegzetességeinek a leírásával kezdődik. Fontos megállapitás, hogy mindenfele antropogén beavatkozás a "társadalmi-gazdasági alakulat igényein ek megfelelóen alakul'. Területenként rendszerezi az antropogén folyamatokat és azok következményeit. Kár, hogy a szintézisben tényszerû̉en közölt, feltehetóen becslés alapján történt megállapításokat nem fejti ki bóvebben, igy ezek megértése nehézséget okoz.

Végül a PÉCSI M--SOMOGYI S.-JAKUCS P. által 1972-ben közölt tájtipológiai rendszer bontásával az antropogén hatások komplex területi típusait ökológiai alapokra épülő rendszerbe foglalja.

A könyvet hét oldalnyi forrásmunka és közel 30 oldalas függelék zárja, amely tartalmazza az egyes ábrákhoz tartozó jelkulcsokat is.

E gazdagon illusztrált, nagy adatbázisra épülő, az ismereteket jól rendszerező, korszerú mondanivalójú átfogó munkát a környezeti problémák iránt érdeklődô olvasók, kutatók, területi tervezók és földrajztanárok egyaránt haszonnal forga thatják.

CSORDÁS LÁSZLO

\section{GEMEINDEN IN DER WIRTSCHAFTSPOLITIK}

(Krista West szerk.)

(A kommunális pénzügy-és gazdaságpolitika lehet6ségei és korlátai lassuló gazdasági növekedés mellett. Kommunalwissenschaftliches Dokumentationszentrum. Wien, 1985. 98 p.)

A bécsi Kommunalwissenschaftliches Dokumentationszentrum (KDZ) kiadványainak sorát gazdagítja a fenti címet viseló könyvecske. Az Intézet fennállásának 15 éves évfordulója adott alkalmat a konferencia megrendezésére, majd az ott elhangzott elöadások egy kötetben történó megjelentetésére. Ausztria és a Német Szövetségi Köztársaság szövetségi, illetve községi vezetôi, valamint a téma elméleti szakemberei gyültek össze. A tanácskozás témája a községnek 1 a helyi és az állami gazdaságpolitikában betöltött szerepe volt. A téma idószer úségét - úgy vélem - nem szuikséges külön indokolni. Éppen ezért helyénvalónak érzem a magyar viszonyokkal való öszszevetést és némi kitekintést.

Az elöadások elméleti kiindulópontja a köz- ségek, mint helyi önkormányzatok pénzügyi és egyúttal gazdaságpolitikai mozgásterének a hetvenes évektól kezdôdó, majd a nyolcvanas években fokozódó beszúk ülése.

Az előadók többsége a krízishelyzet kia lakulását az olajárrobbanások idópontjához kötötte. Napjainkra pedig Keleten és Nyugaton is jellemzóvé vált a helyi bevételi források apadása, anélkül, hogy a helyi feladatok csökkentek volna.

A szerzók a községek pénzügyi mozgástere visszaszerzésének lehetőségeit kutatják; érzékelik mind szövetségi, mind regionális viszonylatban a területi különbségek elmélyülését; vizsgálják - megváltozott feltételek között a községi szolgáltatások és a gazdasági támogatási rendszer helyzetét; taglalják a foglal- 